\title{
UNIVERSALISATION OF EDUCATION IN ODISHA: A GOVERNMENT INITIATIVE
}

\author{
Gayatri Panda ${ }^{1}$ \\ ${ }^{I}$ Research Scholar, Dept of Social Science, F. M. University, Balasore, OR, India
}

\author{
Dr. Kabita Kumari. Sahu ${ }^{2}$ \\ ${ }^{2}$ Professor, P. G. Dept. of Economics, North Orissa University, Baripada, Mayurbhanj, OR, India
}

\begin{abstract}
Education is an important input for empowering people with skill and knowledge and giving them access to productive employment in future. It is an important input as well as output indicators influencing other development indicators of social sector such as health, nutritional status, income, family welfare and others. Both primary and secondary education deserves the highest priority for increasing the competence of the average worker and increasing National productivity. As the provision of universal elementary education is crucial for spreading mass literacy, the provision for secondary education is significant for economic development, modernising social sector and for effective working of democratic institutions. Secondary education serves as a link between the elementary and higher education and plays a very important role in this respect. Since universalisation of elementary education has become a constitutional mandate, it is absolutely essential to push this vision forward to move towards universalisation of secondary education which is already been achieved in a large number of developed countries and several developing countries. The recent focus on secondary education was generated by the 2005 Central Advisory Board of Education Report (2005) and the Rastriya Madhyamik Sikhya Abhiyan (RMSA) initiated in 2009-10 to universalize secondary education by making quality education available, accessible and affordable to all children within the age group of 14-18 years with strong focus on the elements of gender equity and justice. This paper studies the access to an equity and quality in primary and higher secondary education classes (IX-XII) in Odisha and examine some idea for improvements in each.
\end{abstract}

KEYWORDS: Democratic institutions, Initiatives, Literacy, National productivity, Universalisation.

\subsection{INTRODUCTION}

Education in every sense is one of the fundamental factors of development. No nation can achieve sustainable economic development without substantial investment in human capital. It is a significant tool for reducing poverty and unemployment rate in an economy. Therefore the need for literate population and universal education for all children in the age group of 6-18 years is crucial input for nation building and it was given due consideration in the Constitution as well as in the successive five year plan. Lack of education leads to lack of access as well as quality of higher education in particular. Due to the lack of access to or economic compulsion all over in India as well as in Odisha, large sectors of population are deprived elementary and secondary education.

The literacy rate of Odisha during 1951 was $15.8 \%$ which has increased to $72.9 \%$ (Economic Survey 2013-14). The state has been making steady improvements in education front literacy rate in Odisha remaining at per with national average (73\%) 


\section{SJIF Impact Factor 2021: 7.13| ISI I.F.Value:1.241| Journal DOI: 10.36713/epra2016 \\ ISSN: 2455-7838(Online) \\ EPRA International Journal of Research and Development (IJRD) \\ Volume: 6 | Issue: 3 | March 2021 \\ - Peer Reviewed Journal}

registering an increase of $9.8 \%$ points compared to census 2001 (Economic Survey 2016-17).

Universalisation of Elementary Education (UEE) is a constitutional obligation and also a national commitment. The government of Odisha has formulated a number of goals for the education sector like UEE in the state. By 2010 under the Right of Children to Free and Compulsory Education Act 2009, universal literacy, development of secondary and higher secondary education, skill development through vocational education in higher secondary school and modernization of technical education. The Rastriya Madhyamik Sikhya Abhiyan (RMSA) is a flagship programme initiated in 2009-10 to universalise secondary education by making quality education available, accessible and affordable to all children within age group of 14-18 years with strong focus on the elements of gender equity justice.

As per NeighborhoodMapping-2015, out of 90,731 habitations total 87,646 habitations are covered with Primary School facilities and 88,652 with Upper Primary facilities.

- The State Government has relaxed the norm for opening of new primary schools to improve access \& 100 percent enrolment in elementary education. 9,943 number of new primary schools and 11,008 New Upper Primary schools have been opened to provide education to the children of inaccessible areas from 2001 to 2015-16 under SSA.

- Transport/Escort facilities are provided to 1000 children of sparsely populated and scattered habitation.

- Construction of $169 \mathrm{KGBV}$ building has been completed and $13 \mathrm{KGBV}$ building are under progress.

- 65.39 lakh children - in 6-14 age group out of which 65.38 lakh are studying in 68,538 schools and 0.05 lakh children are reported as out of schools are in schools out of which 18.87 lakhs are SC \&30.16 lakh are ST and 48.33 lakh are girl students.

- Free text books have been supplied to all students of all Govt. and aided schools.

- Uniform provided to all girl students and SC / ST, BPL boys in Govt. Schools.

- A comprehensive monitoring mechanism "Samikshya" has been adopted to track performance of elementary education throughout the State.

- 85,500 teachers are engaged and working under SSA to maintain the desirable Pupil Teacher Ratio in Odisha.9,121 new Sikhya Sahayaks have been appointed during 2015-16 under SSA.5,040 no. of newly recruited teachers are trained in 30 days teachers training module.

- 1.02 lakh children with special needs are enrolled in Schools.

- 329 Medical assessment camps have been organized for distribution of assistive devices to 7,063 CWSN and $388 \mathrm{CWSN}$ for surgical correction and teachers provided training on Braille and on sign language.

- 49.27 lakh students of 62,640 primary and upper primary schools are covered under MDM programme.

- 9,344 children of migrant families are retained in 254 seasonal Hostels. 8 residential hostels with intake capacity of 50 each for Urban deprived children, child labour and street children are being opened.

- The School \& mass education Department organized SURAVI 2015 Mela, a State level creative programme for school students at cluster, blocks and district level to encourage students inherent skills. Awareness programme on Bal Swacchata Abhiyan and Swachha Vidyalaya Abhiyan have been organized on 2nd October 2015 across the State

\subsection{OBJECTIVES}

- To highlight the status of elementary and secondary education from 2009-10 to 201516 in Odisha.

- To analyse numbers of enrolment of girls, SC and ST students in elementary and secondary education from 2009-10 to 201516 in Odisha.

- To highlight the Gender disparity in enrolment in elementary and secondary education.

\subsection{UNIVERSALISATION OF SECONDARY EDUCATION}

- To provide secondary school within 5 K.M. and higher secondary school within 7-10 K.M. of every habitation.

- Gross Enrolment Ratio (GER) of 75\% for class-IX \& X within five years (by 201314). Universal Access to Secondary Education (SE) by 2017.

- Universal Retention by 2020.

- Access to Secondary Education (SE) for all disadvantaged group of children.

- To improve quality of education resulting in enhanced intellectual, social and cultural learning.

- 2,608 private high schools have been notified to receive block grant and 399 high schools have been notified during 201516.773 number of new High schools have been sanctioned under RMSA, out of which 745 number of schools have been opened till date.162 model high schools in educationally back ward blocks have been approved. 100 model schools will be made functional from 2016-17.

- $\quad 10,392$ qualified teachers have been engaged on contact basis to maintain Pupil- Teacher ratio in secondary schools. 


\section{EPRA International Journal of Research and Development (IJRD)

- Vocational education is introduced in 30 schools of the State at secondary school stages in automobile, IT \& ITES subjects. OMSA (under RMSA) is the nodal authority run and monitor the vocational education in secondary schools.

- 415 number of Junior SES teachers have been promoted to the posts of Senior SES Headmaster.

- 95 number of teacher (Primary \& Secondary) have been awarded for State Award by the Hon'ble Chief Minister, Odisha during 2015-16.

- In order to enhance the retention rate, 5.40 lakh students belonging to SC/ST/BPL/girls categories have been benefitted under distribution of bicycles to class $\mathrm{X}$ students at the cost of Rs 140.40 crore. Apart from Government High schools, students reading in Sanskrit tolls and Madrasas have been benefited under this scheme

\subsection{ACCESS}

Access to basic education lies at the heart of development. Lack of education is both a part of the definition of poverty and a means for its diminution. Sustained and meaningful access to education is critical to long term improvements in productivity, the reduction of intergenerational cycles of poverty, demographic transition, preventive health care, the empowerment of women, and reductions in inequality. (Streeten, 1999; Sen, 1999).

\subsubsection{Gross Enrolment Ratio}

The GER is calculated by taking the number of children in secondary education and dividing it by the number of children in the relevant age category (in this case 6-11 and 11-14 years of age).The growth of facilities in primary, upper primary and secondary education has been expanding in the state, especially in rural and backward areas. The state aims at providing primary schools within $1 \mathrm{KM}$ and upper primary schools within $3 \mathrm{KM}$ of habitants having population of more than 300 and 500 numbers respectively. There are 4111000 in primary education, 2217000 in upper primary and 1250625 children in secondary education in the year 2015-16. The overall Gross Enrolment Ratio (GER) in class 1 to 8 is $96.50 \%$ which is much larger than secondary class 9 to 10 of 78.28 percent.

Table-1: Gross Enrolment Ratio

\begin{tabular}{|c|c|c|c|c|c|c|c|}
\hline Years & $\mathbf{2 0 0 9 - 1 0}$ & $\mathbf{2 0 1 0 - 1 1}$ & $\mathbf{2 0 1 1 - 1 2}$ & $\mathbf{2 0 1 2 - 1 3}$ & $\mathbf{2 0 1 3 - 1 4}$ & $\mathbf{2 0 1 4 - 1 5}$ & $\mathbf{2 0 1 5 - 1 6}$ \\
\hline Elementary & 99.79 & 101.32 & 101.31 & 100.56 & 102.36 & 97.67 & 96.50 \\
\hline Secondary & 61.40 & 68.76 & 75.03 & 77.03 & 68.65 & 75.43 & 78.28 \\
\hline
\end{tabular}

The number of children in secondary education level is expected to increase due to both supply and demand factors. On the supply side the GER in primary education is over $99 \%$ and is approaching that figure in upper primary. The proportion of children completing primary and upper primary (elementary) education continues to be rise slowly from $89.44 \%$ to $91.25 \%$ in $2013-14$ than it has declined to $88.71 \%$ in the year $2015-16$ (OPEPA
2015-16). But the size of young age group of 15-19 years expected to continue to increase until 2025 (Toby Linden), after that this age group is falling below the current level the current level. On the demand side over the decades the return for secondary and higher secondary education has been the highest demand than elementary level of education (P Gitarani, 2014) and (Das \& Mohapatra, 2013).

Table-2: Total Child Population of the Age Group of 6-14 years

\begin{tabular}{|c|c|c|c|c|c|c|c|c|}
\hline Years & $\begin{array}{c}\mathbf{2 0 0 8 -} \\
\mathbf{0 9}\end{array}$ & $\begin{array}{c}\mathbf{2 0 0 9 -} \\
\mathbf{1 0}\end{array}$ & $\begin{array}{c}\mathbf{2 0 1 0 -} \\
\mathbf{1 1}\end{array}$ & $\mathbf{2 0 1 1 - 1 2}$ & $\mathbf{2 0 1 2 - 1 3}$ & $\mathbf{2 0 1 3 - 1 4}$ & $\mathbf{2 0 1 4 - 1 5}$ & $\mathbf{2 0 1 5 - 1 6}$ \\
\hline 6 - 14 yrs & 145132 & 138966 & 133510 & 148942 & 142090 & 142516 & 148462 & 148050 \\
\hline $6-11 \mathrm{yrs}$ & 91064 & 93177 & 84775 & 102354 & 94243 & 97262 & 102651 & 76957 \\
\hline $11-14$ yrs & 54068 & 45789 & 48735 & 46588 & 47847 & 45254 & 45811 & 71093 \\
\hline
\end{tabular}

Table- 2 shows that total child population of the age group 6-14 years was 91064 in the year 200809 which has declined to 76957 in 2015-16 where as total child population of the age group $11-14$ years were 54068 in the year 2008-09 which has increased to 71093 in $2015-16$. 


\section{EPRA International Journal of Research and Development (IJRD) \\ Volume: 6 | Issue: 3 | March 2021

Fig-1: Child Population

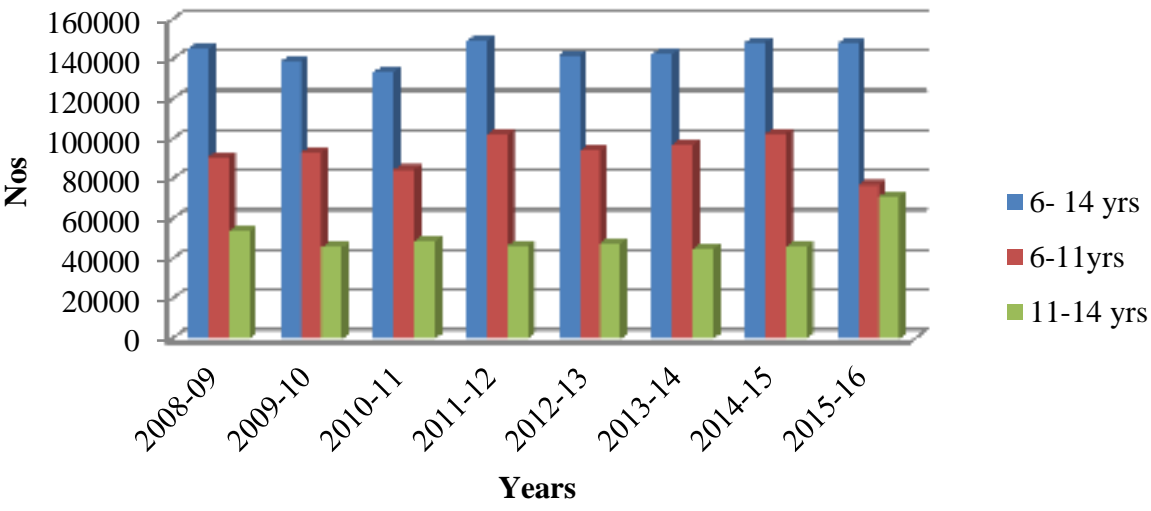

Figure-1 graphs that total child population of the Age

Group 6-11 is less than total child population of the

Age Group 11-14 years.

Table-3: No. of Enrolment in Elementary and Secondary Education

\begin{tabular}{|c|c|r|r|r|r|r|r|r|}
\hline \multicolumn{2}{|c|}{ Years } & $\mathbf{2 0 0 9 - 1 0}$ & $\mathbf{2 0 1 0 - 1 1}$ & $\mathbf{2 0 1 1 - 1 2}$ & $\mathbf{2 0 1 2 - 1 3}$ & $\mathbf{2 0 1 3 - 1 4}$ & $\mathbf{2 0 1 4 - 1 5}$ & $\mathbf{2 0 1 5 - 1 6}$ \\
\hline \multirow{4}{*}{ Elementary } & ALL & 6621741 & 6541072 & 6506551 & 6422415 & 6388057 & 6386483 & 6328084 \\
\cline { 2 - 9 } & SC & 1286720 & 1268033 & 1242605 & 1242721 & 1226588 & 1221185 & 1193839 \\
\cline { 2 - 9 } & ST & 1752901 & 1757794 & 1838120 & 1879778 & 1907581 & 1929530 & 1908715 \\
\cline { 2 - 9 } & GIRLS & 3214255 & 3198774 & 3166185 & 3113377 & 3095017 & 3089318 & 3058382 \\
\hline \multirow{5}{*}{ Secondary } & ALL & 94755 & 1064354 & 11892 & 12004 & 12056 & 1225559 & 1250625 \\
\cline { 2 - 9 } & SC & 19149 & 19812 & 224220 & 22517 & 232580 & 23736 & 24431 \\
\cline { 2 - 9 } & ST & 17146 & 18316 & 215194 & 21491 & 247279 & 24462 & 25753 \\
\cline { 2 - 9 } & GIRLS & 46164 & 52544 & 599329 & 59732 & 599156 & 60655 & 62096 \\
\hline
\end{tabular}

The table 3 represents the numbers of enrolment of girls, SC and ST students in elementary and secondary education from 2009-10 to 2015-16. The numbers of enrolment of sc students in elementary education has declined from 1286720 in 2009-10 to 1193839 in the year 2015-16. The numbers of enrolment of st students in elementary education has increased from 1752901 in 2009-10 to
1908715 in the year 2015-16.But the numbers of girls enrolment has come down from 3214255 in 2009-19 to 3058382 during the year 2015-16.On the other hand the numbers of girls, sc and st enrolment in secondary education has been continuously increasing from 2009-10 to 2015-16.

Table-4: No. of Enrolment in Primary, Upper Primary and Secondary Education

\begin{tabular}{|c|c|c|c|}
\hline years & Primary & $\begin{array}{c}\text { Upper } \\
\text { Primary }\end{array}$ & $\begin{array}{c}\text { Higher } \\
\text { Secondary }\end{array}$ \\
\hline $2000-01$ & 4710 & 1057 & 1083 \\
\hline $2001-02$ & 4769 & 1055 & 1134 \\
\hline $2002-03$ & 4608 & 953 & 1288 \\
\hline $2003-04$ & 5214 & 1363 & 1296 \\
\hline $2004-05$ & 5215 & 1383 & 1304 \\
\hline $2005-06$ & 4602 & 1225 & 1337 \\
\hline $2006-07$ & 4485 & 1817 & 1363 \\
\hline $2007-08$ & 4513 & 1997 & 1379.68 \\
\hline $2008-09$ & 4587 & 2128 & 1442.64 \\
\hline $2009-10$ & 4493 & 2128 & 1455.88 \\
\hline
\end{tabular}




\section{EPRA International Journal of Research and Development (IJRD) \\ Volume: 6 | Issue: 3 | March 2021

\begin{tabular}{|l|c|c|c|}
\hline $2010-11$ & 4489 & 2090 & 1509.54 \\
\hline $2011-12$ & 4433 & 2087 & 1539.88 \\
\hline $2012-13$ & 4341 & 2081 & 1200434 \\
\hline $2013-14$ & 4278 & 2110 & 1205677 \\
\hline $2014-15$ & 4224 & 2163 & 12259 \\
\hline $2015-16$ & 4144 & 2217 & 1250625 \\
\hline
\end{tabular}

The numbers of enrolment of students in primary, upper primary and secondary education is indicated in the table- 4 . The numbers of enrolment of students in primary and upper primary education has gradually declining over the years from 2000-01 to
2015-16 whereas numbers of enrolment of students in secondary education has increased from 1083 thousands in 2000-01 to125062 thousands in 201516.

Table-5: Percentage of Population for 15-19 Age Group

\begin{tabular}{|c|c|c|}
\hline years & Female & Male \\
\hline $2001-02$ & 9.7 & 10.2 \\
\hline $2002-03$ & 10.3 & 10.5 \\
\hline $2003-04$ & 10.2 & 10.4 \\
\hline $2004-05$ & 9.7 & 9.5 \\
\hline $2005-06$ & 10 & 9.9 \\
\hline $2006-07$ & 9.5 & 9.3 \\
\hline $2007-08$ & 10 & 10 \\
\hline $2008-09$ & 9.4 & 9.7 \\
\hline $2009-10$ & 9.6 & 9.9 \\
\hline $2010-11$ & 9.8 & 9.1 \\
\hline $2011-12$ & 9.2 & 10.2 \\
\hline $2012-13$ & 9.2 & 9.9 \\
\hline 2021 predicted & 7.6 & 8.0 \\
\hline
\end{tabular}

Fig.-2 : Percentage of Population for 15-19 Age Group

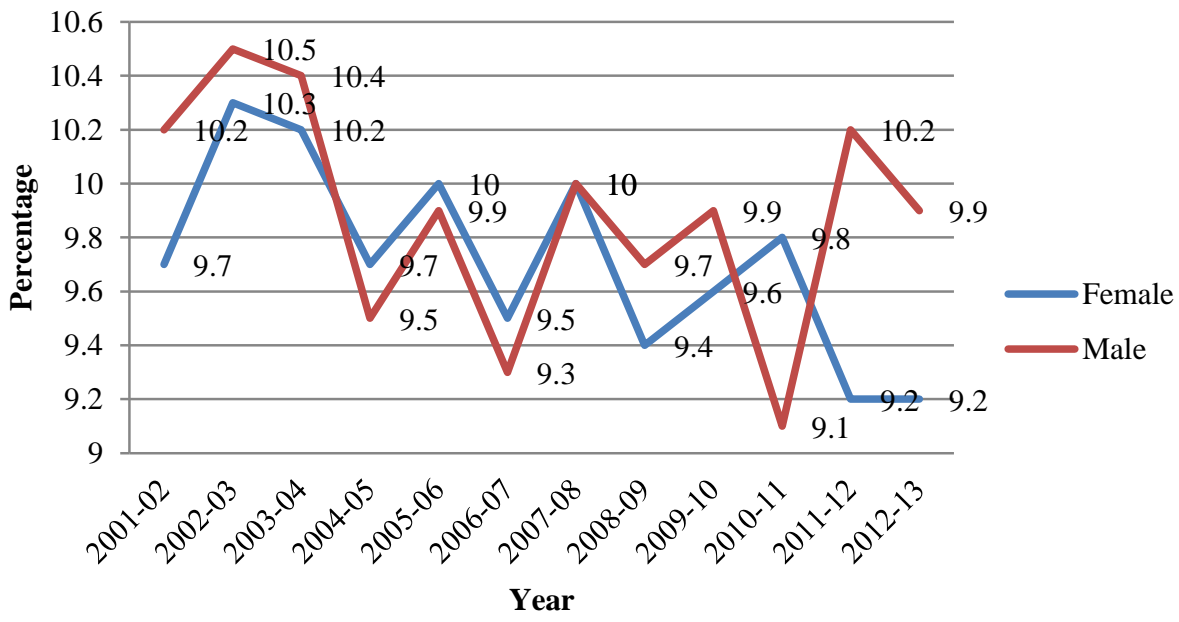




\section{EPRA International Journal of Research and Development (IJRD) \\ Volume: 6 | Issue: 3 | March 2021 \\ - Peer Reviewed Journal}

Table-6: Percentage of Population

\begin{tabular}{|c|c|c|}
\hline $\begin{array}{c}\text { Age } \\
\text { (Years) }\end{array}$ & Female & Male \\
\hline $00-04$ & 8.8 & 9.4 \\
\hline $05-09$ & 8.2 & 8.8 \\
\hline $10-14$ & 9.5 & 10 \\
\hline $15-19$ & 9.2 & 9.9 \\
\hline $20-24$ & 10.4 & 9.2 \\
\hline $25-29$ & 9 & 8 \\
\hline $30-34$ & 8.3 & 8.1 \\
\hline $35-39$ & 7.2 & 7 \\
\hline $40-44$ & 6.6 & 6.9 \\
\hline $45-49$ & 5.2 & 5.5 \\
\hline $50-54$ & 4.1 & 4.7 \\
\hline $55-59$ & 4.1 & 3.4 \\
\hline $60-64$ & 3.2 & 3.3 \\
\hline $65-69$ & 2.4 & 2.4 \\
\hline $70+$ & 3.8 & 3.5 \\
\hline \multicolumn{2}{|c|}{ Source: OPEPA, Statistical Abstract Various Years }
\end{tabular}

Fig.-3: Percentage of Population

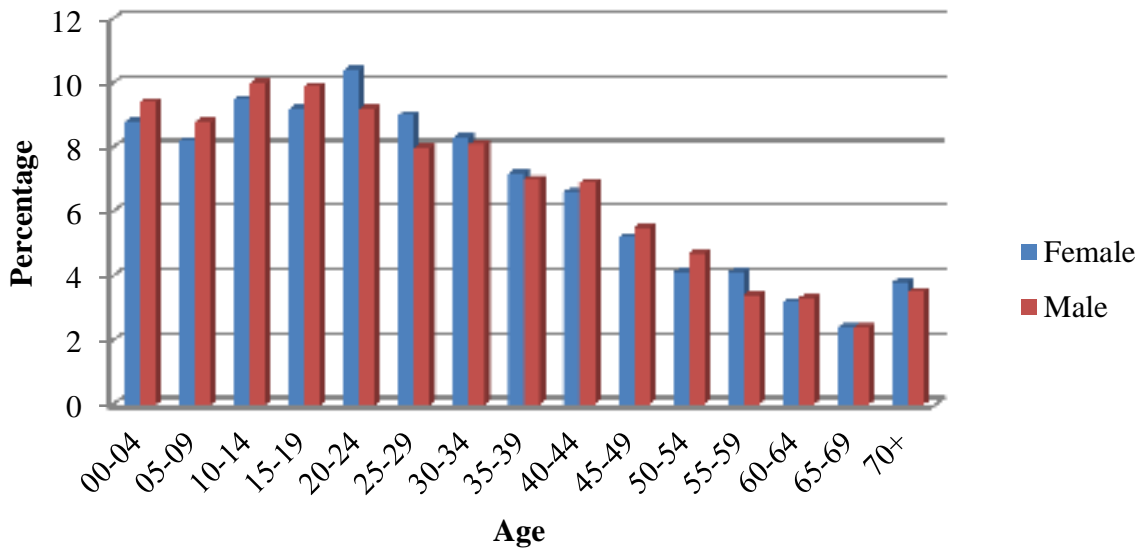

Table-7: Per 1000 Distribution of Unemployment (Age 15 Years and Above) Based on Usual Status by Educational Category of Odisha.

\begin{tabular}{|l|c|c|c|c|c|c|}
\hline \multicolumn{1}{|c|}{ General education } & \multicolumn{7}{c|}{ Rural } & \multicolumn{3}{c|}{ Urban } \\
\cline { 2 - 7 } & Male & Female & Person & Male & Female & Person \\
\hline Not literate (01) & 4 & 99 & 31 & 12 & 0 & 7 \\
\hline Literate up to & 123 & 120 & 122 & 54 & 0 & 30 \\
\hline primary & 278 & 208 & 259 & 66 & 103 & 82 \\
\hline Middle & 332 & 195 & 294 & 170 & 101 & 140 \\
\hline Secondary & 56 & 188 & 92 & 117 & 17 & 73 \\
\hline Higher secondary & 18 & 0 & 13 & 134 & 0 & 75 \\
\hline $\begin{array}{l}\text { Diploma/certificate } \\
\text { course }\end{array}$ & 183 & 187 & 184 & 425 & 401 & 415 \\
\hline Graduate & 6 & 2 & 5 & 21 & 378 & 178 \\
\hline Post graduate & 595 & 573 & 589 & 868 & 897 & 881 \\
\hline Secondary \& above & 1000 & 1000 & 1000 & 1000 & 1000 & 1000 \\
\hline All & & & & & \\
\hline
\end{tabular}

Source: OPEPA, Statistical Abstract Various Years 


\section{EPRA International Journal of Research and Development (IJRD) \\ Volume: 6 | Issue: 3 | March 2021

Per 1000 distribution of unemployment (age 15 years and above) based on usual status by educational category of Odisha shows that the unemployment in elementary education category is less than secondary level. Again unemployment in higher education category such as P.G ,higher secondary, diploma/certificate course than secondary level.

\subsubsection{Nos. of Primary, Upper Primary and High Schools in Odisha}

Patterns of school management of secondary education are complex and vary considerably across states, and even within states between lower and higher secondary.

Table-8: Nos. of Primary, Upper Primary and High Schools in Odisha.

\begin{tabular}{|c|c|c|c|}
\hline Years & Primary & $\begin{array}{c}\text { Upper } \\
\text { Primary }\end{array}$ & $\begin{array}{c}\text { High } \\
\text { School }\end{array}$ \\
\hline $2000-01$ & 42104 & 12406 & 6155 \\
\hline $2001-02$ & 42824 & 11510 & 6282 \\
\hline $2002-03$ & 42824 & 11510 & 6811 \\
\hline $2003-04$ & 44416 & 14233 & 7011 \\
\hline $2004-05$ & 45700 & 15893 & 7408 \\
\hline $2005-06$ & 45890 & 15737 & 7141 \\
\hline $2006-07$ & 46722 & 17322 & 7361 \\
\hline $2007-08$ & 48402 & 18224 & 7435 \\
\hline $2008-09$ & 50062 & 19057 & 7506 \\
\hline $2009-10$ & 52972 & 22209 & 7799 \\
\hline $2010-11$ & 54144 & 24371 & 7974 \\
\hline $2011-12$ & 55106 & 23239 & 8945 \\
\hline $2012-13$ & 55329 & 24234 & 9350 \\
\hline $2013-14$ & 36399 & 21945 & 9423 \\
\hline $2014-15$ & 36550 & 22497 & 9491 \\
\hline $2015-16$ & 36760 & 22795 & 9671 \\
\hline Source: $D P E P$, Statistical Abstract Various Years, Economic Survey Various Years of Odisha
\end{tabular}

Numbers of Upper Primary and High Schools in Odisha has increased12406 and 6155 numbers in the year 2000-01 to 22795 and 9671 respectively in 2015-16. But the numbers of primary school has increased up to 55329 in 2012-13, there after it has declined to 36760 during 2015-16. The compound growth rates of numbers of primary, upper primary and high schools in the state are and respectively.

\subsubsection{Gender Disparity}

The Gender Parity Index (GPI) is a socioeconomic index usually designed to measure the relative access to education of males and females. This index is released by UNESCO Girls are not discriminated against in the state in recent years as regards educational attainment. But because of the initial skewedness, gender disparity in enrolment has not been rectified so far.. As with any educational indicator, gender disparities are conspicuous in regard to enrolment and retention. Girls' enrolment has grown at the primary stage from 24.38 lakhs in 2002-03 to 30.58 lakhs in 2015-16 and at the upper primary stage from 520394 to 1018744 from the year 2004-05 to 2011-12 and from 618.03 thousand to 735.48 thousand at the secondary stage. The rate of growth of enrolment of girls has been higher than that of boys but disparities still persist - girls still account for only 45.7 per cent of the enrolment at the elementary stage and 37.73 percent in secondary stage. Many of the equity gaps will be closed over time merely due to the expansion of secondary education. The differences across sub-populations in terms of access are almost nonexistent at the primary level and in states where overall participation rates are high (Sankar 2011).

$$
\text { Gender Parity Index : } \frac{\text { No of girls enrolled }}{\text { No of boys enrolled }}
$$




\section{EPRA International Journal of Research and Development (IJRD) \\ Volume: 6 | Issue: 3 | March 2021 \\ - Peer Reviewed Journal}

Table - 9: Gender Parity Index

\begin{tabular}{|c|c|c|c|c|c|c|c|}
\hline Year & $\mathbf{2 0 0 9 - 1 0}$ & $\mathbf{2 0 1 0 - 1 1}$ & $\mathbf{2 0 1 1 - 1 2}$ & $\mathbf{2 0 1 2 - 1 3}$ & $\mathbf{2 0 1 3 - 1 4}$ & $\mathbf{2 0 1 4 - 1 5}$ & $\mathbf{2 0 1 5 - 1 6}$ \\
\hline Elementary Education & 0.94 & 0.95 & 0.95 & 0.96 & 0.96 & 0.94 & 0.94 \\
\hline Secondary Education & 1.00 & 0.98 & 0.97 & 0.98 & 1.04 & 1.01 & 0.99 \\
\hline
\end{tabular}

The gender parity index is the ratio of number of girls to number of boys enrolled. The gender parity index in elementary and secondary education is presented in table-9. The table shows that the gender parity index in elementary level is above 0.90 In the Secondary level gender parity index is above0. 95 from the year

\subsection{EQUITY}

\subsubsection{Numbers of Teachers in Odisha}

A well-qualified and motivated teaching force is to be seen as one of the most vital assets for educational quality

The growth in the numbers of teachers in elementary and secondary schools in Odisha is presented in the table 10 .

Table - 10: Nos. of Primary, Upper Primary and High School Teachers in Odisha.

\begin{tabular}{|c|c|c|c|}
\hline \multirow{2}{*}{ Years } & \multicolumn{3}{|c|}{ Number of Teachers } \\
\cline { 2 - 4 } & Primary & $\begin{array}{c}\text { Upper } \\
\text { Primary }\end{array}$ & $\begin{array}{c}\text { High } \\
\text { School }\end{array}$ \\
\hline $2000-01$ & 114794 & 40706 & 51570 \\
\hline $2001-02$ & 116231 & 38914 & 52389 \\
\hline $2002-03$ & 83652 & 41375 & 58136 \\
\hline $2003-04$ & 97175 & 49786 & 60960 \\
\hline $2004-05$ & 99079 & 31393 & 61008 \\
\hline $2005-06$ & 115351 & 32985 & 61939 \\
\hline $2006-07$ & 114105 & 39832 & 62094 \\
\hline $2007-08$ & 123765 & 49413 & 62727 \\
\hline $2008-09$ & 125434 & 55832 & 63303 \\
\hline $2009-10$ & 137833 & 56758 & 64967 \\
\hline $2010-11$ & 136407 & 53994 & 65289 \\
\hline $2011-12$ & 133262 & 53264 & 62799 \\
\hline $2012-13$ & 134578 & 53791 & 49389 \\
\hline $2013-14$ & 121193 & 62570 & 49997 \\
\hline $2014-15$ & 122214 & 74647 & 51078 \\
\hline $2015-16$ & 133541 & 72472 & 62704 \\
\hline Source: OPEPAA Statistical Abstract Various Years, Economic Survey Various Years of Odisha
\end{tabular}

Numbers of teachers in odisha in primary ,upper primary and high school from 2000-01 to 2015-16 are presented in the table. The compound growth rates of teachers in primary ,upper primary and high school from 2000-01 to 2015-16 are respectively. The number of primary school teachers in Odisha increased from 1.14 lakh in 2000-01 to1.33 lakh in 2015-16. The numbers of upper primary school teachers increased from 40.7 thousands to 72.4 thousands and the numbers of high school teachers has moved up 51.57 thousands in 2000-01 to 62.70 thousands in 2015-16. 


\section{EPRA International Journal of Research and Development (IJRD) \\ Volume: 6 | Issue: 3 | March 2021

\subsubsection{Pupil Teacher Ratio}

Table - 11: Pupil Teacher Ratio

\begin{tabular}{|c|c|c|c|c|c|c|c|}
\hline Years & $\mathbf{2 0 0 9 - 1 0}$ & $\mathbf{2 0 1 0 - 1 1}$ & $\mathbf{2 0 1 1 - 1 2}$ & $\mathbf{2 0 1 2 - 1 3}$ & $\mathbf{2 0 1 3 - 1 4}$ & $\mathbf{2 0 1 4 - 1 5}$ & $\mathbf{2 0 1 5 - 1 6}$ \\
\hline Elementary & 28.77 & 30.03 & 27.8 & 26.95 & 25.57 & 25.46 & 24.29 \\
\hline Secondary & 28.77 & 30.03 & 27.8 & 26.95 & 23.42 & 23.34 & 23.06 \\
\hline
\end{tabular}

Pupil Teacher Ratio in elementary and secondary education is presented in the tableindicates that the ratio in elementary education has declined from 28.77 percent in $2009-10$ to 24.29 percent in 2015-16. In case of secondary education the ratio has moved down from 28.77 percent in 2009-10 to 23.03 percent in 2015-16

\subsection{QUALITY}

\subsubsection{Transition, Repetition, Promotion} Rate

Higher education is of vital importance for the country, as it is a powerful tool to build knowledgebased society of the 21 st Century. The effectiveness or achievement of an education system in serving its stake holders, the students is reflected by transition, retention, promotion and repetition rates. Primary to secondary transition rate is the proportion of pupils (total, male, female) in the last grade of primary who are promoted to the first grade of secondary the following school year. Repetition rate, primary or secondary is the proportion of pupils (total, male, female) in any grade of primary or secondary in a given school year and who also attend that same grade in the following school year. Pupils who actually move backwards from one school year to the next are counted as repeaters Promotion rate, primary or secondary is the proportion of pupils (total, male, female) in any grade of primary or secondary school who are promoted to the next grade the following school year. Sometimes, this rate includes a small number of pupils who move forward more than one grade in the following school year.

Table-12: Transition, Repetition, Promotion Rate

\begin{tabular}{|l|l|c|c|c|c|}
\hline \multicolumn{2}{|l|}{ Years } & $\begin{array}{c}\mathbf{2 0 1 2 -} \\
\mathbf{1 3}\end{array}$ & $\begin{array}{c}\mathbf{2 0 1 3 -} \\
\mathbf{1 4}\end{array}$ & $\begin{array}{c}\mathbf{2 0 1 4 -} \\
\mathbf{1 5}\end{array}$ & $\begin{array}{c}\mathbf{2 0 1 5 -} \\
\mathbf{1 6}\end{array}$ \\
\hline \multirow{3}{*}{ Elementary } & $\begin{array}{l}\text { Transition Rate (P to } \\
\text { UP) }\end{array}$ & 85.54 & 87.05 & 91.06 & 91.32 \\
\cline { 2 - 6 } & Repetition Rate & 3.7 & 2.29 & 0.65 & 0.08 \\
\cline { 2 - 6 } & Promotion Rate & 96.3 & 95.53 & 96.72 & 96.58 \\
\hline \multirow{3}{*}{ Secondary } & $\begin{array}{l}\text { Transition Rate (VIII to } \\
\text { IX) }\end{array}$ & 91.01 & 97.39 & 94.76 & 92.88 \\
\cline { 2 - 6 } & Repetition Rate & 2.94 & 2.13 & 0.32 & 0.31 \\
\cline { 2 - 6 } & Promotion Rate & 84.82 & 86.48 & 85.32 & 95.18 \\
\hline
\end{tabular}

Transition Rate (P to UP), Repetition Rate and Promotion Rate in the elementary education was 85.54 percent, 3.7 percent and 96.3 percent respectively and Transition Rate (VIII to IX) Repetition Rate and Promotion Rate in the secondary education was 91.01 percent, 2.94 percent and 84.82 percent in the year 2012-13
The Board of Secondary Education, Odisha and Council of Higher Secondary Education, Orissa regulates the secondary and higher secondary education in Odisha. In addition, 182 schools affiliated to CBSE/ICSE also provide +2 level educations. The overall percentage of success rate in examinations conducted by BSE and CHSE from 2004-05 to 2016-17 is given on the table 13 . 


\section{EPRA International Journal of Research and Development (IJRD) \\ Volume: 6 | Issue: 3 | March 2021

Table - 13: Results of Secondary \& Higher Secondary Education in Odisha.

\begin{tabular}{|c|c|c|c|c|c|c|}
\hline & \multicolumn{3}{|c|}{ Secondary Education } & \multicolumn{3}{|c|}{ Higher Secondary Education } \\
\hline Year & $\begin{array}{c}\text { BSE, } \\
\text { Odisha }\end{array}$ & $\begin{array}{c}\text { CBSE, } \\
\text { New } \\
\text { Delhi }\end{array}$ & $\begin{array}{l}\text { ICSE, New } \\
\text { Delhi }\end{array}$ & $\begin{array}{c}\text { CHSE, } \\
\text { Odisha }\end{array}$ & $\begin{array}{c}\text { CBSE, } \\
\text { New } \\
\text { Delhi }\end{array}$ & $\begin{array}{l}\text { ICSE, New } \\
\text { Delhi }\end{array}$ \\
\hline $\begin{array}{c}2004- \\
05\end{array}$ & 52.3 & 89.3 & 93.2 & 71.11 & 84.7 & 91 \\
\hline 2005- & 49.72 & 88.6 & 95.9 & 64.20 & 89.8 & 90 \\
\hline 2006- & 56.62 & 94 & 98.9 & 58.64 & 89.9 & 97 \\
\hline 2007- & 47.92 & 94.85 & 93.3 & 62.45 & 89.4 & 97 \\
\hline $2008-$ & 59.56 & 95.08 & 98 & 70.52 & 90.3 & 97 \\
\hline 2009- & 69.17 & 95.5 & 98 & 71.82 & 89.7 & 94.2 \\
\hline $2010-$ & 58.67 & 99.8 & 98.5 & 69.54 & 90.5 & 94.9 \\
\hline 2011- & 62.3 & 99.22 & 98.8 & 70.79 & 82.3 & 94.2 \\
\hline 2012- & 84.7 & 99.25 & 98.7 & 70.14 & 84.1 & 91.6 \\
\hline 2013- & 84.25 & 99.83 & 97.92 & 68.37 & 87.86 & 89.7 \\
\hline 2014- & 82.56 & 99.48 & 98.25 & 76.75 & 80.77 & 93.38 \\
\hline 2015- & 85 & 98.48 & 98.22 & 73.63 & 83.03 & 92.34 \\
\hline
\end{tabular}

The table indicates that the percentage of success rate is continuously increasing over the year's from2004-05 to 2015-16 in high school certificate examinations but the rate was quite below the result of CBSE and CHSE result. The wide variations between state and central board examinations in secondary and higher secondary level indicate a lack of technical reliability in the examinations. Therefore, there is no state picture of the quality of secondary education, as measured by the skills and knowledge acquired by students at the end of this stage of education.

\subsubsection{Dropout Rates}

The problem gets more complicated as the drop-out rates, though declining, continue to be high. Nearly half the children who entered Class I drop out before reaching Class $\mathrm{V}$ and two-thirds of the children dropout before reaching Class VIII. Regional disparities also abound in rates of the dropouts. The 42nd round of the National Sample Survey (July 1986-June 1987) provides valuable information on the reasons for non-enrolment and dropout. However, nearly 30 percent of the persons surveyed, both in rural and urban India, gave the reason for "never enrolled" as being "not interested". The difference between the sexes here is large: a larger proportion of "never enrolled" females gave this reason in comparison with the males. The reason for being "not interested" could be considered as a demand side constraint to access: some authorities however, consider it as a supply side constraint rooted in poor facilities and quality of education.
Urban "dropouts" cited 'failure' to pass examinations as the reason for discontinuance. Again, it is a debatable point whether this is a supply side constraint due to the poor quality of education services or a demand constraint, or a combination of both. Still about 6.3 percent of urban males and 19.6 percent of urban females are illiterates. participation in household economic activity and other economic reasons. Attending to domestic chores restrained around one percent of the males, both in rural as well as urban India, from ever enrolling as students Most of the young females are denied access to education because they look after their siblings besides performing a variety of domestic, housekeeping chores. Therefore this reason was one of the major demand side constraints on access to education for the females. Because of the affirmative policies of the government, the enrolment of SCs and STs has increased considerably at the primary stage. Dropout rate is one of the downbeat indicators of educational intensification. It reflects the internal inefficiency of the education system. Dropout rate increases with movement from lower to higher class/grade. In Odisha, the dropout rates exhibit a decreasing trend over the years but still remain very high among the ST in all students. Drop-outs, though declining over the years, are significantly large among SC, ST and girls. Dropout rate in the primary or secondary is the proportion of pupils (total, male, female) in any grade of primary or secondary in a given school year and who no longer attend school the following school year. 


\section{EPRA International Journal of Research and Development (IJRD) \\ Volume: 6 | Issue: 3 | March 2021 \\ - Peer Reviewed Journal}

Table-14: Dropout Rates

\begin{tabular}{|c|c|c|c|c|c|c|c|c|}
\hline \multicolumn{2}{|c|}{ Year } & $\begin{array}{c}\mathbf{2 0 0 9 -} \\
\mathbf{1 0}\end{array}$ & $\begin{array}{c}\mathbf{2 0 1 0 -} \\
\mathbf{1 1}\end{array}$ & $\begin{array}{c}\mathbf{2 0 1 1 -} \\
\mathbf{1 2}\end{array}$ & $\begin{array}{c}\mathbf{2 0 1 2 -} \\
\mathbf{1 3}\end{array}$ & $\begin{array}{c}\mathbf{2 0 1 3 -} \\
\mathbf{1 4}\end{array}$ & $\begin{array}{c}\mathbf{2 0 1 4 -} \\
\mathbf{1 5}\end{array}$ & $\mathbf{2 0 1 5 - 1 6}$ \\
\hline \multirow{4}{*}{ Elementary } & ALL & 5.51 & 4.92 & 1.75 & 1.38 & 2.19 & 2.63 & 3.34 \\
\cline { 2 - 10 } & SC & 6.31 & 4.8 & 2.07 & 2.39 & 2.49 & 2.48 & 4.05 \\
\cline { 2 - 9 } & ST & 8.09 & 6.35 & 3.9 & 2.98 & 3.17 & 5.91 & 7.95 \\
\cline { 2 - 9 } & GIRLS & 5.67 & 5.09 & 1.42 & 1.32 & 2.07 & 2.74 & 3.15 \\
\hline \multirow{5}{*}{ Secondary } & ALL & 25.83 & 22.91 & 19.71 & 18.72 & 16.49 & 14.36 & 6.02 \\
\cline { 2 - 10 } & SC & 27.21 & 23.37 & 21.73 & 23.19 & 16.34 & 17.06 & 6.15 \\
\cline { 2 - 9 } & ST & 26.53 & 25.85 & 23.46 & 25.04 & 19.02 & 18.9 & 10.52 \\
\cline { 2 - 9 } & GIRLS & 19.28 & 18.64 & 16.44 & 16.21 & 14.61 & 13.74 & 5.18 \\
\hline
\end{tabular}

Source: OPEPA 2015-16

The table indicates that dropout rates in secondary education has declining trend but it is still high in case of st in comparison to sc and girl students. Again dropout rates in elementary education was lowest in the year 2012-13.the dropout rate is higher in secondary schools in comparison to elementary schools.

Table-15: Dropout Rates Among Girls, SC and ST Students in Odisha.

\begin{tabular}{|c|c|c|c|c|c|c|c|c|c|}
\hline \multirow{2}{*}{ years } & \multicolumn{3}{|c|}{ Primary } & \multicolumn{3}{c|}{ Upper Primary } & \multicolumn{3}{c|}{ High Schools } \\
\cline { 2 - 10 } & Girls & SC & ST & Girls & SC & ST & Girls & SC & ST \\
\hline $2001-02$ & 40 & 51 & 63 & 60.5 & 58.5 & 73 & 72 & 76 & 78 \\
\hline $2002-03$ & 36.5 & 37.2 & 53.3 & 60.5 & 47.5 & 77.7 & 68.5 & 75.3 & 77.3 \\
\hline $2003-04$ & 35.4 & 35.6 & 52.4 & 58.6 & 63.1 & 75.8 & 66.7 & 74 & 75.8 \\
\hline $2004-05$ & 32.7 & 34.8 & 52 & 50.1 & 55 & 69.5 & 66 & 72.5 & 75.3 \\
\hline $2005-06$ & 18.86 & 19.46 & 23.32 & 28.96 & 29.33 & 37.07 & 64 & 71.7 & 74 \\
\hline $2006-07$ & 7.83 & 16.97 & 22.88 & 18.47 & 25.59 & 32.44 & 62 & 70.9 & 74 \\
\hline $2007-08$ & 4.89 & 12.54 & 16.89 & 13.49 & 18.8 & 23.83 & 61 & 70 & 72.8 \\
\hline $2008-09$ & 3.1 & 7.96 & 10.69 & 8.43 & 11.92 & 15.12 & 60.6 & 69.6 & 71.6 \\
\hline $2009-10$ & 3.1 & 4.36 & 6.46 & 8.24 & 8.89 & 9.72 & 55.2 & 64.4 & 69.2 \\
\hline $2010-11$ & 2.86 & 3.89 & 4.85 & 7.31 & 6.21 & 7.85 & 52.1 & 61 & 65.4 \\
\hline $2011-12$ & 0.62 & 2.68 & 3.1 & 2.23 & 1.73 & 4.7 & 51.8 & 60.5 & 64.3 \\
\hline $2012-13$ & 0.22 & 2.42 & 2.77 & 2.38 & 2.41 & 3.38 & 16.21 & 21.2 & 23.4 \\
\hline $2013-14$ & 2.05 & 2.39 & 2.71 & 2.08 & 2.58 & 3.63 & 14.6 & 16.3 & 19 \\
\hline $2014-15$ & 1.78 & 1.13 & 3.75 & 4.25 & 4.45 & 5.03 & 13.74 & 17.06 & 18.9 \\
\hline $2015-16$ & 2.92 & 3.3 & 7.07 & 3.52 & 4.8 & 8.82 & 5.18 & 6.15 & 10.52 \\
\hline Source: Economic Survey Various Years of Odisha & & & & & & \\
\hline
\end{tabular}

Table 15 shows that drop-out rates among girls, SCs and STs in primary and upper primary education have continuously declining up to 2013-14 but it has again started increasing over the years. But in the secondary education girls, SCs and STs dropout rates has been continuously declining from 72, 76 and 78 percent in 2001-02 to 5.18, 6.15 and 10.52 percent respectively in the year 2015-16.
1.6.3 Status of Infrastructure Facilities in Primary and Secondary Schools

Infrastructure facilities in schools have a direct bearing on enrolment and dropout rates. The State Government is making concerted efforts with its available resources to reduce the drop-out rate. In spite of all out efforts of Government for strengthening infrastructure facilities in elementary education still a long way to achieve the target. Lack 


\section{EPRA International Journal of Research and Development (IJRD) \\ Volume: 6 | Issue: 3 | March 2021 \\ - Peer Reviewed Journal}

of basic facilities at Government elementary school

from 2010-11 2015-16 is presented in the table

Table-16: Status of Infrastructure in Government Elementary Schools

\begin{tabular}{|c|c|c|c|c|c|c|c|}
\hline \multirow{2}{*}{ YEAR } & \multirow{2}{*}{$\begin{array}{c}\text { GOVT. } \\
\text { SCHOOL }\end{array}$} & \multicolumn{2}{|c|}{ NO TOILET } & \multicolumn{2}{c|}{$\begin{array}{c}\text { HAVING } \\
\text { FURNITURE FOR }\end{array}$} & \multirow{2}{*}{$\begin{array}{c}\text { NO } \\
\text { BUILDING }\end{array}$} & $\begin{array}{c}\text { NO } \\
\text { DRINKING } \\
\text { WATER }\end{array}$ \\
\cline { 3 - 6 } & & BOYS & GIRIS & ALL & SOME & & 6002 \\
\hline $2010-11$ & 52150 & 26737 & 36656 & 1076 & 10283 & 651 & 2922 \\
\hline $2011-12$ & 53094 & 16621 & 34824 & 1167 & 10824 & 523 & 2346 \\
\hline $2012-13$ & 53193 & 12588 & 27516 & 1497 & 11824 & 354 & 1714 \\
\hline $2013-14$ & 52890 & 12364 & 7497 & 2523 & 15294 & 267 & 1207 \\
\hline $2014-15$ & 53455 & 9439 & 6267 & 1182 & 10816 & 373 & 289 \\
\hline $2015-16$ & 53252 & 2927 & 946 & 1168 & 10757 & 376 & \\
\hline
\end{tabular}

Expanding access will require both public and private investments, given the needs and the distribution of management types. Govt expenditure on general education has risen rapidly over the years.

Table-17: Secondary Schools having Percentage of Infrastructural Facilities Year 2014-15

\begin{tabular}{|l|c|}
\hline School having Building & 99.48 \\
\hline School having drinking water facility & 99.2 \\
\hline Schools having boys toilet & 81.58 \\
\hline Schools having girls toilet & 90.23 \\
\hline Schools having boundary walls & 77.03 \\
\hline School having playground facilities & 66.39 \\
\hline Schools having electricity connection & 67.06 \\
\hline School with Ramp facilities & 61.16 \\
\hline School with Library facilities & 95.5 \\
\hline School with single classroom & 1.01 \\
\hline Source: Odisha at a glance-2016, Directorate of Economics and Statistics, Odisha, Bhubaneswar
\end{tabular}

The table shows that the infrastructural facilities are not completely available in all the schools. Secondary schools go without Building drinking water facility boys toilet girls toilet boundary walls playground facilities electricity connection Ramp facilities Library facilities and single classroom are

\subsubsection{Govt. Revenue Expenditure on General Education}

Table -18: Shows the Revenue Expenditure on General Education from the Year 2004-05 to 2015 -

\section{6 in Odisha.}

\begin{tabular}{|c|c|c|c|c|c|c|c|c|c|c|c|c|}
\hline Years & $\mathbf{2 0 0 4 - 0 5}$ & $\mathbf{2 0 0 5 - 0 6}$ & $\begin{array}{c}\mathbf{2 0 0 6 -} \\
\mathbf{0 7}\end{array}$ & $\begin{array}{c}\mathbf{2 0 0 7 -} \\
\mathbf{0 8}\end{array}$ & $\begin{array}{c}\mathbf{2 0 0 8 -} \\
\mathbf{0 9}\end{array}$ & $\begin{array}{c}\mathbf{2 0 0 9 -} \\
\mathbf{1 0}\end{array}$ & $\begin{array}{c}\mathbf{2 0 1 0 -} \\
\mathbf{1 1}\end{array}$ & $\begin{array}{c}\mathbf{2 0 1 1 -} \\
\mathbf{1 2}\end{array}$ & $\begin{array}{c}\mathbf{2 0 1 2 -} \\
\mathbf{1 3}\end{array}$ & $\begin{array}{c}\mathbf{2 0 1 3 -} \\
\mathbf{1 4}\end{array}$ & $\begin{array}{c}\mathbf{2 0 1 4 -} \\
\mathbf{1 5}\end{array}$ & $\mathbf{2 0 1 5 - 1 6}$ \\
\hline Expenditure & 1954.76 & 2261.79 & 2404.18 & 3171.22 & 4386.26 & 5413.18 & 6279.84 & 6647.48 & 7050.72 & 8065.6 & 9558.74 & 10826.04 \\
\hline
\end{tabular}

Table 18 highlighted that the Government expenditure on general education in Odisha has been increasing over the years from 1954.76 crores in 2004-05 to 10826.04 crores during $2015-16$. 


\section{SJIF Impact Factor 2021: 7.13| ISI I.F.Value:1.241| Journal DOI: 10.36713/epra2016 \\ EPRA International Journal of Research and Development (IJRD) \\ Volume: 6 | Issue: 3 | March 2021}

- Peer Reviewed Journal

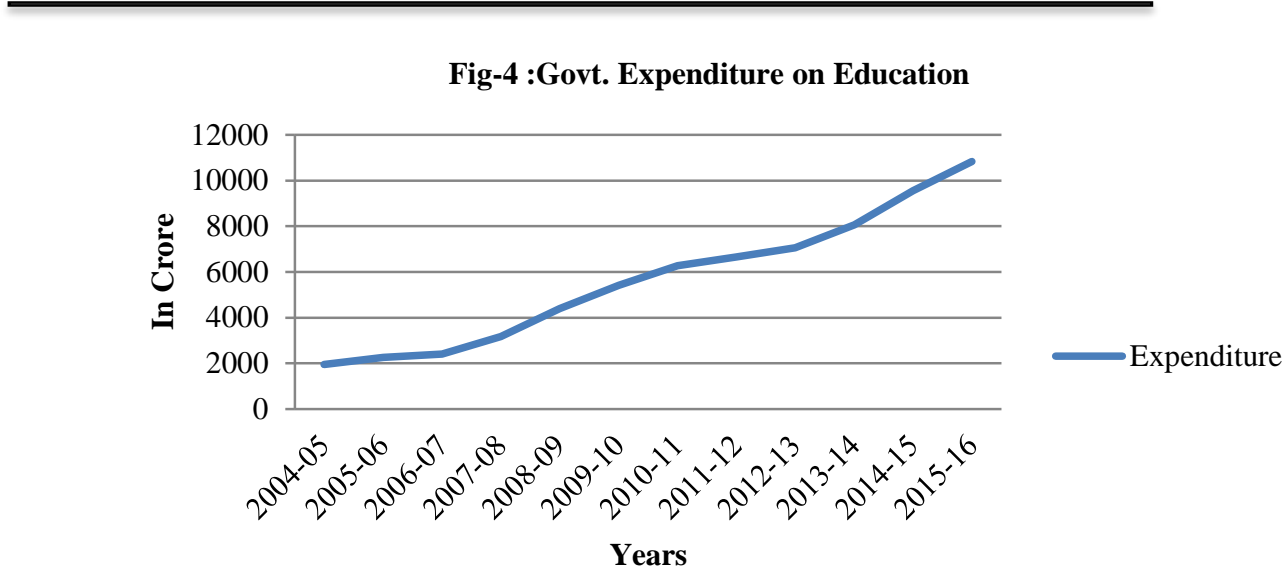

Figure 4 represents that govt expenditure on general education has continuously increasing trends over the years

\subsection{CONCLUSION}

Any government policy or programme that seek out improvements in the access, quality and equity of elementary secondary education needs to recognise two complexities: the differences between elementary and secondary education, and the various models of school governance. First, there are significant differences between elementary and secondary schools, so it cannot be assumed that lessons learnt in one sub-sector can be applied to the other. There are differences between elementary and secondary schools in terms of size, organisation, relationship to their communities/parents, and ways of assessing quality. So one should not assume that patterns in elementary education will work in secondary schools; for example, there is a lot of evidence that parents can hold elementary teachers and schools accountable, under certain conditions. But this accountability framework that produces positive results in primary education depends critically on certain features that are not present in secondary schools: (a) parents can understand measures of quality (such as basic reading and mathematical skills), (b) parents form a reasonably coherent community because the primary school draws its students from a single village or residential area, and (c) the social distance between parents and the teachers is not too great. These features do not hold in secondary education. School Management Development Committees (SMDCs) have been introduced in secondary schools following the broadly positive experience of such committees in primary education. However, considerable work will be needed to help them become effective instruments of school accountability. Second, as already noted, the management arrangements in secondary education are signifi cantly diff erent from those in elementary education with diff erent combinations of government, aided and unaided schools across states and within states across lower and higher secondary education. Any policy or programme should take account of these differences. This indicates the importance of promoting and evaluating diff erent approaches. Given these complexities, a single solution that will be relevant and applicable to the whole of the secondary education sector and across different states is highly unlikely. Thus, there should be attempts to encourage innovation and experimentation, within a strong monitoring and evaluation framework. improving quality of education by making all secondary schools conform to prescribed norms; removing gender, socioeconomic and disability barriers; providing universal access to elementary secondary level education Dropout rates in the schools have declined but it still remains a matter of concern specifically in the tribal dominated backward regions. The growth in the number of secondary schools in the state is still low. Pupil-teacher ratio is declining over the years. Both an appreciable proportion of elementary and secondary schools in the state are deficient in basic infrastructural facilities like drinking water facilities, separate toilet for girls and boys and furnitures. It has demoralizing effect on the pupils who are discouraged to stay in the school for a longer period. The dull character of most of the schools and their poor capacity to attract students and retain them lead to wastage. Teachers should be recruited from the same area, in which they would like to serve. Hence the recruitment policy should be changed as regards appointment of teachers.

To attract men of quality, lucrative and enhanced pay-scales should be given to teachers. An attempt should be made to reduce the number of pupils per teacher. It should be $25=1$. Spread of education among the scheduled castes and tribes, and among girls particularly in rural areas needs special attention.

The government is explicitly encouraging this in the case of the RMSA programme, having created innovation activities through which local actors and states can develop their own ideas about how to improve access, equity and quality. The lessons from 
these ideas will also then seed the development of the RMSA programme

\section{REFERENCES}

1. Sen, A. K. (1999) Development as Freedom. Oxford: Oxford University Press.

2. Streeten, P. (1999) Ten Years of Human Development. Human Development Report. New York: UNDP.

3. IOSR Journal of Humanities And Social Science (IOSR-JHSS) Volume 20, Issue 3, Ver. V1 (Mar. 2015), PP 09-20 e-ISSN: 2279-0837, p-ISSN: 2279-0845. www.iosrjournals.org DOI: 10.9790/0837-20330920 www.iosrjournals.org 9 | Page Status of Secondary Education in Odisha Manasi Dash1 1 (Research Scholar, Department of Analytical and Applied Economics, Utkal University, Bhubaneswar,

4. ISSN 2348-3156 (Print) International Journal of Social Science and Humanities Research ISSN 2348-3164 (online) Vol. 4, Issue 1, pp: (300305), Month: January - March 2016, Available at: www.researchpublish.com Page | 300 Research Publish Journals Secondary Education in India: Issues and Concerns Dr. Priti Chaudhari Assistant Professor in, Department of Education [CASE], Faculty of Education and Psychology, The Maharaja Sayajirao University of Baroda, Vadodara- 390002.

5. Sangeeta \& Kumar, J. / Educationia Confab ISSN: 2320-009X Vol. 2, No. 5, May 201328 Support of Rashtriya Madhyamik Shiksha Abhiyan (RMSA) to Achieve the EFA Goal Ms. Sangeeta* \& Dr. Jitendra Kumar***Research Scholar, MJRP University, Jaipur, Rajasthan \& NGO Worker, Delhi, India **Assistant Professor, DPBS (PG) College, Anoopshahr, Bulandshahr,uttarpradesh,india

6. STATUS AND PROBLEMS OF EDUCATIONAL SCENARIO OF PARTICULARLY VULNERABLE TRIBAL GROUPS IN ODISHA : GOVERNMENT INITIATIives, Minaketan Behera* Journal of Economic \& Social Development, Vol. - X, No. 1, July, 2014 ISSN 0973 - 886X. 